\title{
PENERAPAN STRATEGI PQ4R (PREVIEW, QUESTION, READ, REFLECT, RECITE, REVIEW) UNTUK MENINGKATKAN AKTIVITAS DAN HASIL BELAJAR SISWA KELAS X IPS SMA PGRI MEGALUH JOMBANG MATERI NILAI MUTLAK
}

\author{
Yayuk Setyaningsih ${ }^{1}$, Aslih Maulana ${ }^{2}$ \\ SMA PGRI Megaluh Jombang ${ }^{1}$ \\ Program Studi PPG, Universitas Muhammadiyah Gresik ${ }^{2}$ \\ ysetyaningsih786@gmail.com
}

\begin{abstract}
Abstrak
Pada umumnya tidak semua siswa mampu memahami suatu materi dengan membaca buku teks. Biasanya guru selalu memerintahkan siswa untuk membaca materi dari buku teks guna meningkatkan pemahamannya. Banyaknya materi dan adanya keterbatasan waktu juga merupakan penyebab guru memerintahkan siswa untuk membaca sendiri materi tersebut dari buku. Berdasarkan tentang penerapan strategi belajar PQ4R guna meningkatkan hasil belajar siswa dan aktivitas siswa dalam mempelajari materi nilai mutlak dengan pengajaran langsung.

Penelitian dilakukan pada siswa kelas X IPS semester 1 di SMA PGRI Megaluh Jombang yang berjumlah 30 siswa. Pendekatan yang digunakan adalah Penelitian Tindakan Kelas (PTK) yang dilaksanakan dalam 2 kali siklus. Setiap siklus terdiri atas tahap rencana, tindakan/observasi, refleksi dan revisi. Data untuk mengetahui peningkatan hasil belajar siswa diperoleh dari nilai kuis pada setiap akhir siklus. Kemudian nilai ini dianalisis dengan batas ketuntasan dan ketercapaian IPK. Sedangkan untuk mengetahui peningkatan aktivitas siswa diperoleh dari lembar pengamatan aktivitas siswa. Penilaian yang diperoleh dianalisis secara deskriptif.

Hasil dari penelitian memberikan simpulan bahwa penerapan strategi belajar PQ4R dapat meningkatkan hasil belajar matematika pada siswa dengan rata-rata nilai tertinggi dicapai pada siklus II yaitu sebesar 91,3 dengan ketuntasan klasikal $100 \%$. Sedangkan aktivitas siswa juga mengalami peningkatan dengan rata-rata tertinggi sebesar 3,43 pada siklus II.
\end{abstract}

Kata kunci: Strategi Belajar PQ4R, Pengajaran Langsung

\begin{abstract}
Abstrack
Generally, not all of the studens are able to understand a topic discussion by reading texts book. Usually the teacher always ask the students to read the material based on the texts book to increase their understanding. The overload of material capacity and the limited time are caused the teacher ask the students to read the book's material by self. Based on the statemens, the researcherstimulated to do her research about implementation strategy in learning Preview, Question, Read, Reflect, Recite, Review (PQ4R) to increase the result of studying matemathics and student activity the material absolute value with direct method.

This research is to be done to the student of SMA PGRI Megaluh Jombang at first semester of class X IPS which consists of 35 students. The stimulation which used is classaction research that to be done in 2 time cycles. Every cycle is consisting of planning step, action/observation, reflection, and revision. The data that used in the student 'sresearch is to know the increasing of the result study from the quiz in every cycle ending. Then the point is to be analyzed with the minimal point and minimal IPK.
\end{abstract}


While to knowthe increasing of the student's activity is gotten from the data of the student'sactivity research. The pointing which to be gotten isto be analized in descriptive.

The result of the research gives conclusion that the implementation of strategy in learning $P Q 4 R$ is able to increase the result of studying mathematics to the student with the higeest poin rates which is reached on the cycles II, there are 91,3 with classical point 100\%. While the student activity also has increasing with the highest rates with point 3.43 at cycle II.

Keywords: Strategy of Learning PQ4R, Direct Method

\section{PENDAHULUAN}

Mata pelajaran matematika merupakan salah satu ilmu yang berkembang pesat, baik materi maupun kegunaannya. Matematika tidak dapat dipelajari dari lingkungan saja, melainkan membutuhkan bantuan guru atau bukubuku teks. Sehingga siswa mendapatkan berbagai informasi tentang rumus-rumus matematika. Ilmu yang lain pun membutuhkan matematika sebagai alat bantu dalam menyelesaikan masalah yang dihadapi, karena matematika adalah ratu sekaligus pelayan ilmu pengetahuan. Jadi, penguasaan matematika yang baik merupakan dasar yang kuat untuk mempelajari bidang yang lain.

Tujuan pendidikan pada dasarnya mengantarkan para siswa menuju pada perubahan-perubahan tingkah laku, baik intelektual, moral, maupun sosial. Dalam mencapai tujuan tersebut, siswa diharuskan berinteraksi dengan lingkungan belajar yang diatur oleh guru melalui proses pengajaran, bahan pengajaran, metode pengajaran, dan penilaian pengajaran. Metode mengajar merupakan suatu cara atau teknik mengajar topiktopik tertentu yang disusun secara teratur dan logik (Hudojo, 2001:108) .

Berdasarkan pengalaman penulis mengajar di SMA PGRI Megaluh Jombang, proses pembelajaran yang selama ini dilihat membuat siswa kurang bersemangat dalam memperhatikan penjelasan guru. Selain itu peserta didik kurang aktif dalam bertanya kepada guru dan juga kurang aktif dalam memperhatikan presentasi temantemannya. Artinya siswa hanya sebagai pendengar saja. Kejadian-kejadian seperti itulah yang tidak mengherankan dan membuat hasil belajar matematika cenderung menjadi rendah.

Usaha yang telah penulis lakukan yaitu memberikan pelajaran dengan berbagai metode seperti metode ceramah, diskusi, bahkan sampai mempresentasikan secara individu dan berkelompok, bahkan juga memberikan latihan supaya dapat memecahkan masalah dan membuat peserta didik lebih paham dan mengerti 
tentang pembelajaran matematika. Akan tetapi peserta didik masih ada yang kurang memahami pelajaran matematika tersebut. Misalnya dalam mengoperasikan tanda Plus $(+)$ dan Min $(-)$ pada aljabar, seringkali peserta didik tersebut sulit membedakan tanda tersebut. Contoh $-2 \times$ -3 , siswa mengartikan hasilnya -6 tanpa melihat terlebih dahulu tanda min (-) atau plus $(+)$. Kurangnya minat membaca sebagai hal yang sangat dirasakan. Tersedianya buku-buku pelajaran serasa tidak berarti. Untuk mengatasi masalah tersebut, perlu dilakukan usaha yang dapat meningkatkan keaktifan siswa dalam pembelajaran matematika dan itu semua tidak terlepas dari usaha dan kemampuan siswa itu sendiri untuk mengubah dirinya menjadi lebih baik dalam memahami pelajaran pada umumnya dan matematika pada khususnya.

Untuk mengikuti tuntutan kurikulum dan meningkatkan hasil belajar matematika peserta didik, maka salah satu usaha yang harus dilakukan oleh seorang guru adalah menggunakan strategi pembelajaran yang dapat mengaktifkan peserta didik untuk belajar lebih optimal. Peneliti menggunakan sebuah strategi yang dapat menuntun peserta didik untuk dapat menemukan sendiri bagaimana cara penyelesaian permasalahan matematika yaitu dengan menggunakan strategi PQ4R.
Penerapan strategi PQ4R meningkatkan aktifitas dan hasil belajar matematika siswa dengan baik. PQ4R dikemukakan oleh Thomas dan Robinson pada tahun 1972 (Nur, 2000:34). PQ4R merupakan singkatan dari Preview (membaca selintas dengan cepat), Question (bertanya), Read (membaca), Reflect (refleksi), Recite (tanya jawab sendiri), Review (mengulang secara menyeluruh). Nur (2000:34) mengemukakan bahwa siswa yang menggunakan strategi PPQ4R akan diperintahkan untuk mendekati suatu tugas bacaan dengan menggunakan langkahlangkah berikut ini.

Langkah 1. Preview, tugas membaca. Membaca materi pelajaran secara cepat untuk mendaatkan suatu ide tentang pengorganisasian umum dan topictopik utama. Memperhatikan juduljudul, membaca tinjauan umum serta rangkuman dan meramalkan akan membahas tentang apa.

Langkah 2. Question, mendalami topik-topik dan judul-judul utama dan mengajukan pertanyaanpertanyaan yang jawabannya dapat ditemukan di dalam bacaan tersebut.

Langkah 3. Read, membaca bahan dan memberikan perhatian pad ideide utama dan mencari jawaban- 
jawaban atas pertanyaan yang diajukan pada langkah 2

Langkah 4. Reflect, melakukan refleksi sambil membaca, menciptakan gambaran visualdari bacaan dan mencobauntuk menghubungkan informasi baru di dalam bacaan dengan apa yang telah diketahui.

Langkah 5. Review, mengulang kembali seluruh bacaan, membaca ulang bila perlu dan sekali lagi menjawab pertanyaan-pertanyaan yang diajukan.

Tujuan penerapan strategi belajar ini agar para peserta didik dapat bekerja secara mandiri dan bertanggungjawab. Sehingga dapat meminimalkan kesalahan pemahaman konsep karena materi dibaca secara berulang-ulang dengan pemahaman. Adanya strategi PQ4R diharapkan akan lebih memudahkan peserta didik untuk mengembangkan kemampuan berfikir.

\section{METODE}

Penelitian ini merupakan Penelitian Tindakan Kelas (PTK). PTK, bukan merupakan penelitian eksperimental yang dilakukan di laboratorium, tetapi merupakan penelitian yang bersifat praktis dan berdasarkan kepada permasalahan keseharian di sekolah. Subjek penelitian ini adalah siswa kelas X IPS SMA PGRI Megaluh Jombang Tahun Pelajaran 2019/2020 dengan jumlah 30 siswa. Pelaksanaan penelitian ini dibagi dalam 2 tahapan kegiatan. Tahap pertama yaitu persiapan penelitian yang berlangsung pada bulan September, tahap kedua yaitu pelaksanaan tindakan yang berlangsung pada bulan Oktober 2019.

Data pada penelitian ini diperoleh dengan menggunakan metode observasi dan metode tes. Metode observasi dipakai untuk memperoleh data mengenai kemampuan guru mengelola pembelajaran di kelas dan aktivitas peserta didik yang beracuan pada instrument pengamatan. Sedangkan metode tes dipakai untuk memperoleh data berupa nilai yang berkisar antara 0-100 pada tiap tes. Jenis data dalam penelitian ini adalah data kuantitatif. Sedangkan instrumen penelitian yang digunakan dalam penelitian adalah tes hasil belajar dan lembar pengamatan proses pembelajaran.

Pada Penelitian Tindakan Kelas, setiap siklus terdiri atas 4 tahap (Riyanto, 2007:139), yaitu : (1) rencana, (2) tindakan dan observasi, (3) refleksi, serta (4) revisi. Adapun siklus PTK dapat dijelaskan dengan bagan sebagai beriku: 


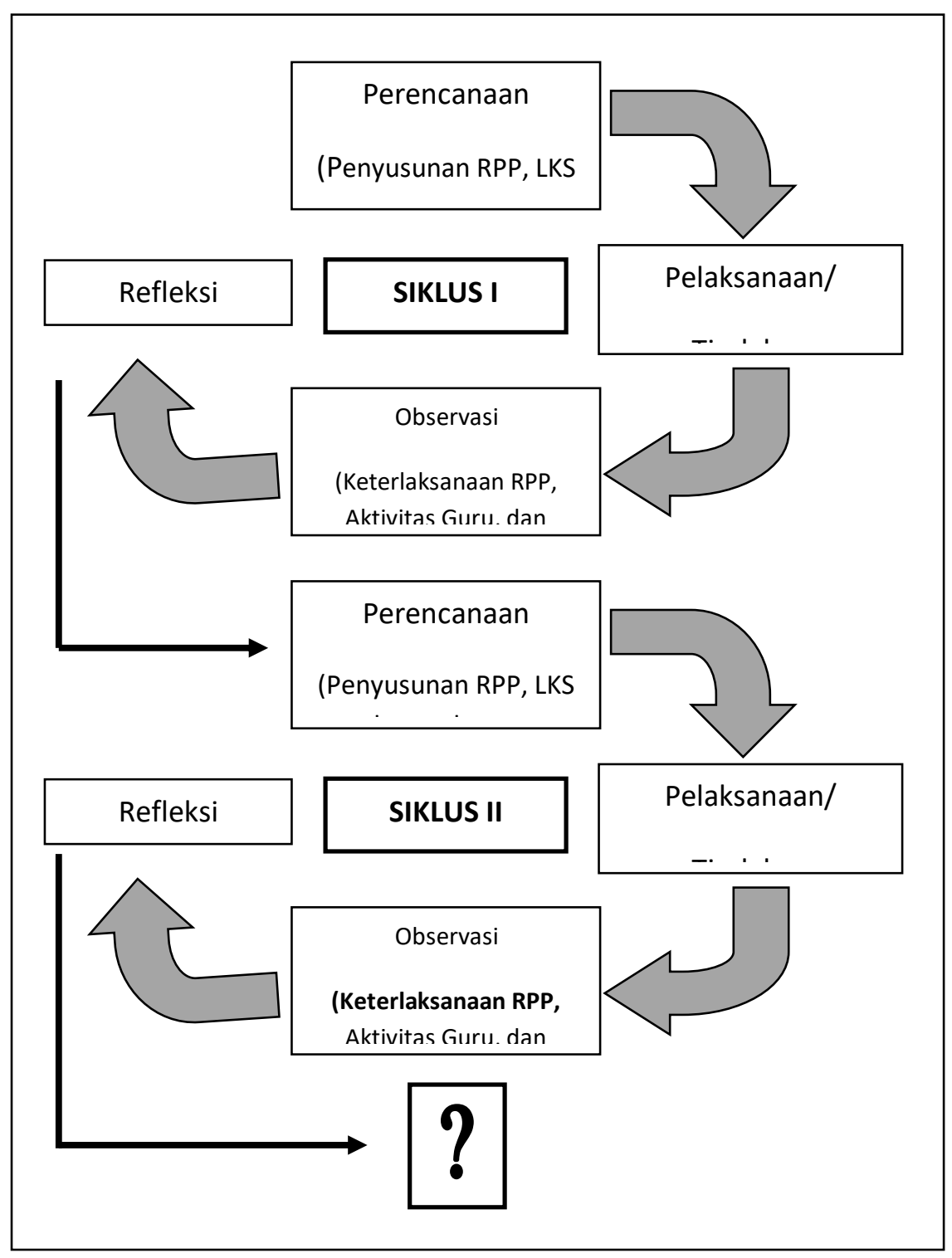

Gambar 1. Siklus Penelitian Tindakan Kelas

Adapun data berupa nilai yang diperoleh dengan mengadakan kuis pada tiap siklus akan di analisis dengn batas ketuntasan siswa yang ditentukan dengan rumus ketuntasan belajar peserta didik secara klasikal berikut:

$\frac{\text { Jumlah siswa yang mendapat nilai } \geq 70}{\text { Jumlah seluruh siswa }} \times 100 \%$

Selain itu juga dilakukan perhitungan ketercapaian IPK yang ditentukan dengan rumus:

$$
P=\frac{n}{N} \times 100 \%
$$

Keterangan:

$\mathrm{P}=$ persentase ketercapaian IPK

$\mathrm{N}=$ jumlah siswa yang menjawab sesuai dengan IPK

$\mathrm{N}=$ jumlah seluruh peserta didik

Sedangkan data observasi pada dari instrument lembar pengamatan pengelolaan pembelajaran dikelas dan lembar pengamatan aktivitas peserta didik 
akan di analisis dengan menggunakan ratarata, yaitu:

$$
\text { Rata }- \text { rata }=\frac{\sum \text { nilai yang diperoleh }}{\sum \text { aspek yang diamati }}
$$

Sementara data tentang keterampilan $P Q 4 R$ yang diperoleh dari lks di analisis dengan memberikan nilai berdasarkan lembar keterampilan $P Q 4 R$ yaitu:

$$
\text { Nilai }=\frac{\text { Skor yang diperoleh siswa }}{\text { Skor maksimum }} \times 100 \%
$$

Kriteria keberhasilan dari penelitian tindakan ini adalah adanya peningkatan aktivitas dan hasil belajar selama proses pembelajaran berlangsung. Dari jumlah skor indikator tersebut diperoleh angka yang menunjukkan skor aktivitas belajar dengan strategi PQ4R selama pembelajaran. Secara klasikal dikatakan aktivitas belajar peserta didik berhasil jika mendapat kriteria minimal baik. Sedangkan untuk hasil belajar peserta didik dikatakan berhasil jika secara klasikal mencapai 70\%.

\section{HASIL DAN PEMBAHASAN}

\section{Hasil belajar siswa}

Siklus I. Hasil belajar pada siklus I dari 30 siswa hanya 7 siswa yang tidak tuntas belajarnya, sedangkan yang tuntas ada 23 siswa. Ini berarti telah mencapai ketuntasan klasikal sebesar $77 \%$. hasil belajar siklus I yang diperoleh dari nilai kuis 01 nilai rata-ratanya hanya sebesar 78,40. Nilai rata-rata hasi belajar yang tidak begitu tinggi ini disebabkan karena siswa belum terbiasa dengan metode PQ4R. Pembelajaran dengan metode PQ4R selalu diakhiri dengan kuis. Siswa SMA PGRI Megaluh salama ini tidak pernah diberi kuis untuk mengecek pemahamannya. Sehingga saat diberi kuis pada siklus I hasilnya kurang memuaskan. Selain itu, materi persamaan nilai mutlak merupakan materi yang terpanjang dan sulit. Sesuai dengan yang dituliskan oleh Ahmadi dan Supriyono (1991:131) bahwa prestasi belajar dipengaruhi oleh beberapa factor diantaranya yaitu panjangnya bahan pelajaran. Materi persamaan nilai mutlak ini terdapat konsep-konsep garis bilangan. Makin sulit suatu bhan pelajaran, makin lambat orang memelajarinya dan mengakibatkan prestasi belajarnya tida begitu baik. Panjangnya bahan pelajaran tersebut membutuhkan waktu yang lama untuk mempelajarinya. Sebagian orang ada yang dapat belajar dengan waktu yang cepat namun ada juga yang butuh waktu lama untuk belajar. Hal ini tentu saja berpengaruh terhadap prestasi belajarnya.

Siklus II. Hasil belajar pada siklus II mengalami peningkatan dari 30 siwa yang ikut kuis semuanya berhasil memperoleh nilai di atas 70. Ini berarti telah mencapai ketuntasan klasikal 100\%. Hasil belajar siklus II yang diperoleh dari 
nilai kuis 02 rata-ratanya sebesar 91,3. Hasil belajar yang meningkat pada siklus II disebabkan karena materi pertidaksamaan nilai mutlak materinya sedikit. Sedikitnya bahan pelajaran tersebut dibutuhkan waktu yang sedikit pula untuk mempelajarinya. Hasil belajar yang meningkat padasiklus II juga disebabkan karena siswa mulai terampil menggunakan metode PQ4R untuk mempelajri suatu materi. Berdasarkan tabel 4.5 diketahui bahwa nilai rata-rata keterampilan PQ4R siswa sebesar 86,7. Nilai rata-rata yang tinggi ini menandakan bahwa siswa sudah mengusai metode PQ4R dengan baik. Dengan menggunakan metode PQ4R mereka dapat memahami materi dan mengrjakan soal kuis sehingga hasil belajarnya meningkat. Hal ini sesuai dengan pendpat Slameto yang menyatakan bahwa belajar yang baik apabila $40 \%$ waktu digunakan untuk mebaca dan $60 \%$ untuk resitasi atau menyatakannya kembali.

\section{Aktivitas siswa}

Aktivitas siswa pada siklus I hanya memiliki rata-rata nilai sebesar 2,43. Kecilnya nilai rata-rata aktivitas siswa disebabkan ada satu aktivitas yang tidak dilakukan oleh siswa yaitu merangkum pembelajara dalam bentuk tanya jawab mendapat nilai 1 . Siswa tidak merangkum pembelajaran karena guru kurang mampu mengelola waktu, akibatnya guru tidak sempat melakukan penutup. Hal ini dapat dilihat padalembar pengelolaan pembelajaran dengan metode PQ4R pada siklus I. Aspek pengelolaan waktu hanyamendapat nilai 2 yang berarti cukup baik. Penutup tidak sempat dilakukan karena guru menghabiskan banyak waktu untuk menjelaskan dan memodelkan strategi belajar PQ4R. Straregi belajar PQ4R ini baru pertama kali diajarkan kepada siswa sehingga perlu di ulang berkali-kali. Di samping itu aktivitas siswa lainnnya yaitu mendengarkan penjelasan guru hanya mendapat nilai 2 . Ini disebabkan guru kurang mampu dalam mengelola kelas. Guru dianggap kurang bisa mengelola kelas karena beberapa siswa ada yang ramai dan bicara sendiri. Kelas menjadi ramai terutama saat guru memeriksa pemahaman siswa tentang penerapan strategi belajar PQ4R. Pengajaran tentang strategi belajar PQ4R menggunakan pengajaran langsung. Pengajaran langsung memerintahkan siswa untuk mendemonstrasikan strategi belajar PQ4R secara utuh. Saat mendemonstrasikan strategi beljar PQ4R diperlukan waktu yang lama. Terpaksa guru hanya menunjuk seorang siswa untuk mendemonstrasikan PQ4R sementra siswa yang lainnya tidak dilibatkan. Masalah tersebut diatasi dengan memecah strategi PQ4R dalam komponen-komponennya ketika didemonstrasikan oleh siswa. Strategi PQ4R terdiri atas enam komponen 
yaitu Preview, Question, Read, Reflect, Recite, dan Review. Keenam komponen tersebut akan didemonstrasikan secara berurutan oleh enam siswa. Satu siswa mendemonstrasikan satu komponen. Bila pembelajaran dilakukan seperti ini maka kondisi kelas akan terjaga sebab siswa sibuk menunggu giliran untuk mendemonstrasikan PQ4R sehingga tidak ramai sendiri.

Aktivitas siswa pada siklus II ratarata nilainya meningkat daripada siklus I yaitu sebesar 3,14. Peningkatan rata-rata nilai ini berhubungan dengan semakin baiknya kemampuan guru mengelola pembelajaran dengan metode PQ4R. Guru sudah bisa mengelola kelas sehingga semua siswa mau mendengarkan penjelasan guru dan tidak ramai sendiri. Pembelajaran dengan metode PQ4R ditekankan pada kegiatan membaca (Read), sehingga kesempatan siswa untuk berbicara dengan temannya sedikit karena sibuk membaca materi dari buku teks. Kondisi ini sangat membantu guru agar dapat mengelola kelas. Selai itu, guru jua sudah bisa mengelola waktu sehingga siswa dapat merangkum pembelajaran dalamm bentuk tanya jawab.

Berdasarkan pembahasan diatas, dapat dikatakan bahwa metode PQ4R mampu meningkatkan aktivitas siswa kelas $\mathrm{X}$ IPS SMA PGRI Megaluh Jombang dalam mempelajari materi persamaan dan pertidaksamaan nilai mutlak. Adapun aktivitas siswa yang mengalami peningkatan melalui metode PQ4R adalah mendengarkan penjelasan guru, mendemonstrasikan di depan kelas dan merangkum pembelajaran dalam bentuk tanya jawab.

\section{Ketercapaian IPK}

Pada siklus I semua IPK tercapai. Indicator nomor 1 yaitu menjelaskan konsep nilai mutlak tercapai 74,33\%. Hal ini disebabkan siswa kurang memahami konsep-konsep nilai mutlak. Indikator nomor 2 yaitu menentukan penyelesaian persamaan nilai mutlak tercapai $81,11 \%$

Pada siklus II, berdasarkan data yang disajikan pada tabel 4.5 terlihat bahwa IPK telah tercapai seluruhnya serta mengalami peningkatan dari pada siklus I yaitu $88,67 \%$ dan 91\%. Berdasarkan analisis tersebut dapat dikatakan bahwa penerapan strategi PQ4R dapat meningkatkan persentaseketercapaian IPK secara klasikal.

\section{Ketercapaian IPK}

Keterampilan PQ4R pada siklus I nilai rata-rata hanya sebesar 72,9 . Dari 30 siswa hanya19 yang dianggap terampil menerapkan PQ4R sedangkan sisanya 11 dianggap tidak terampil. Banyaknya siswa yang tidak tuntas dalam menerapkan PQ4R ini disebabkan oleh faktor pengajar yaitu guru. Guru memiliki suara yang pelan sehingga tidak terdengar oleh siswa 
yang duduk dibangku belakang atau siswa yang memiliki daya pendengaran rendah. Salah satu aktivitas siswa yaitu mendengarkan penjelasan guru hanya memperoleh nilai 2 . Suara guru yang pelan tidak terdengar oleh siswa yang duduk dibangku paling belakang menyebabkan siswa menjadi ramai dan bicara sendiri. Penyebab lain dari ketidak tuntasan siswaadalah karena strategi belajar PQ4R baru diajarkan untuk pertama kalinya sehingga siswa masih belum bisa menguasai tahap-tahapannya. Terutama tahap Question dan Read. Sebagian siswa membuat pertanyaan yang tidak sesuai dengan IPK yang ada. Contoh pertanyaaanya misalnya nilai dari $-5+$ $6=\ldots$. Siswa seharusnya sudah mengetahui jawabannya karena sudah pernah diajarkan. Hal ini membuktikan bahwa pengetahuan awal dan pengalaman belajar sangat penting untuk mempelajari materi yang baru.

Keterampilan siswa menerapkan strategi PQ4R pada siklus II nilai rataratanya mengalami peningkatan dari siklus I yaitu 72,9 menjadi 86,7. Sedangkan ketuntasan klasikalnya sebesar 93\%. Karena dari 30 siswa hanya 2 yang tidak tuntas belajarnya sedangkan 28 sisanya dinyatakan tuntas. Penimgkatan ini terjadi karena pada siklus II siswa telah berlatih menerapkan keterampilan PQ4R untuk yang kedua kalinya, sehingga siswa sudah terbiasa menerapkan strategi PQ4R serta menguasai tahap-tahapnya.

Berdasarkan hasil dan pembahasan diatas membuktikan bahwa strategi PQ4R dapat membantu siswa dalam memahami informasi dari bacaan. Oleh karena itu melakukan Preview dan mengajukan pertanyaan-pertanyaan sebelum membaca mengaktifkan pengetahuan awal dan mengawali proses pembuatan hubungan antara informasi baru dengan apa yang telah diketahui. Mempelajari judul-judul dan topik-topik utama membantu perpindahannya dari memori jangka pendek ke memori jangka panjang.

\section{PENUTUP}

\section{Simpulan}

Berdasarkan hasil penelitian dan pembahasan yang telah diuraikan dimuka, maka dapat disimpulkan sebagai berikut:

1. Penerapan strategi belajar PQ4R dapat meningkatkan hasil belajar siswa kelas X IPS SMA PGRI Megaluh Jombang pada materi Nilai Mutlak yang meliputi persamaan dan pertidaksamaan nilai mutlak. Hsil belajar siklus II lebih tinggi dibandingkan dengan siklus I. Rata-rata pada siklus II yaitu sebesar 91,3 dengan ketuntasan klasikal $100 \%$. 
2. Penerapan strategi belajar PQ4R dapat meningkatkan aktivitas siswa kelas X IPS SMA PGRI Megaluh Jombang dalam mempelajari nilai mutlak. Rata-rata aktivitas siswa secara klasikal pada siklus II lebih tinggi bila dibandingkan dengan siklus I. Rata-rata ativitas siswa secara klasikal pada siklus II yaitu 3,14 .

3. Keterampilan siswa menerapkan metode PQ4R untuk mempelajari materi nilai mutlak secara bertahap mengalami kemajuan pada setiap siklus.

\section{Saran}

Berdasarkan hasil penelitian yang telah dilakukan, maka ada beberapa saran yang dapat dikemukakan, yaitu sebagai berikut ini:

1. Guru (peneliti) harus mengubah istilah Preview, Question, Read, Reflect, Recite, dan Review (PQ4R) ke dalam bahasa Indonesia agar mudah diterima oleh siswa. Jadi istilah Preview, Question, Read, Reflect, Recite, dan Review (PQ4R) ke dalam Bahasa Indonesia akan menjadi membaca sekilas, bertanya, membaca

cermat, menghubungkan informasi baru dan lama, Tanya jawab sendiri, dan mengulang secara menyeluruh.

2. Mengembangkan penerapan strategi belajar PQ4R pada materi lain.

3. Pada saat penerapan strategi belajar PQ4R hendaknya guru selalu mempersiapkan diri dengan baik sebelum melaksanakan pembelajaran sehingga hasil pembelajaran lebih maksimal dan guru selalu menciptakan suasana belajar yang menyenangkan sehingga dapat meminimalkan kejenuhan dalam diri siswa

\section{DAFTAR PUSTAKA}

Hudojo, H. Heran, M.Ed. 2001. Pengembangan Kurikulum dan Pembelajaran Matematika. Malang: Universitas Negeri Malang.

Nur, M. 2000. Strategi-strategi Belajar. Surabaya: Universitas Negeri Surabaya.

Riyanto, Yatim. 2007. Metodologi Penelitian Pendidikan Kualitatif dan Kuantitatif. Surabaya: UNESA University Press. 